\title{
A variation of the thyroid cartilage: Absence of left superior cornu
}

\section{Tiroid kıkırdağın bir varyasyonu: Sol üst boynuz yokluğu}

\author{
Mehmet İlkay Koşar ${ }^{1}$, *Hasan Tetiker ${ }^{1}$, Ceren Uğuz Gençer ${ }^{1}$, Yasemin Balcı ${ }^{2}$, Mu- \\ rat Şahan ${ }^{3}$ \\ ${ }^{1}$ Department of Anatomy, Muğla Sıtkı Kocman University School of Medicine, Muğla, Turkey \\ ${ }^{2}$ Department of Forensic Medicine, Muğla Sıtkı Koçman University School of Medicine, Muğla, Turkey \\ ${ }^{3}$ Department of Otorhinolaryngology, Muğla Sitkı Koçman University School of Medicine, Muğla, Turkey \\ Corresponding author: Dr. Hasan Tetiker, Anatomi Anabilim Dalı, Muğla Sıtkı Koçman Üniversitesi Tıp Fakültesi, TR- \\ 48000 Muğla, Türkiye \\ E-mail: hasantetiker@gmail.com \\ Received/Accepted: March 05, 2015/May 25, 2015 \\ Conflict of interest: There is not a conflict of interest.
}

\section{SUMMARY}

The agenesis of superior cornu is one of the congenital or acquired abnormalities of the thyroid cartilage. Superior cornu may not be present congenitally or may be dislocated subsequently. The agenesis of superior cornu may be diagnosed as a fracture mistakenly. In this article, 70-year-old male patient is presented who did not have left superior cornu of thyroid cartilage which was detected by autopsy.

Keywords: Superior cornu, thyroid cartilage, larynx anomaly, autopsy, agenesis

ÖZET

Üst boynuz yokluğu, tiroid kıkırdağın konjenital veya edinsel anormalliklerinden biridir. Üst boynuz doğuştan bulunmayabilir veya sonradan disloke olabilir. Üst boynuz yokluğu yanlışlıkla kırık olarak teşhis alabilir. Bu yazıda otopsi sonucu tesbit edilen, tiroid kıkırdağın sol üst boynuzu bulunmayan 70 yaşında bir erkek olgu sunulmuştur.

Anahtar sözcükler: Üst boynuz, tiroid kıkırdağı, larinks anomalisi, otopsi, agenezi

\section{INTRODUCTION}

The thyroid cartilage is the largest cartilage of the larynx skeleton. Thyroid cartilage and cricoid cartilage form together the major part of the front and side parts of laryngeal skeleton. Thyroid cartilage consists of two bilateral laminae which combine at the front with about an angle of 120 degrees in women and an angle of 90 degrees in men. Laminae resemble a rectangle and contain projections extending up and down called as superior and inferior cornua ${ }^{1}$. The superior cornu, which is longer and narrower, turns upwards, backwards and medial and ends with a conical apex. The lateral thyrohyoid ligament extending between the apex of the superior cornu and greater horn of the hyoid bone is the thickened rear portion of thyrohyoid membrane.

Laryngeal region is a region that is particularly carefully examined for forensic medicine. The superior cornu of thyroid cartilage may be dislocated as a result of trauma as in hanging and strangulation events. However, it may be possible that the superior cornu is not developed congenitally. In this article, it was aimed to create awareness by presenting a case without superior cornu of thyroid cartilage determined by autopsy.

\section{CASE REPORT}

It has been determined in an autopsy conducted by a forensic expert that 70-yearold man died due to cardiovascular disease. It was detected on the throat examination that hyoid bone and thyroid carti- 
lage were intact.

The superior cornu of the thyroid cartilage was not found at its anatomical site. Hyoid-laryngeal complex was totally excised (Figure 1). When this specimen was viewed from the posterior, it was observed that the greater horns of the hyoid bone were not in the same horizontal plane and the left pyriform recess was more narrow and short. Laryngeal cartilage skeleton was dissected by starting from both two pyriform recesses and protecting laryngeal mucosa (Figure 2). It was detected that the greater horns of hyoid bone were in their place and intact, and thyrohyoid membrane was intact. The morphological differences (sclerosis, fibrosis) suggesting a previous trauma were not observed in the dissection of thyrohyoid membrane and the surrounding tissue. There was no anatomical variation except the superior cornu agenesis in the selective dissection of the thyroid cartilage.

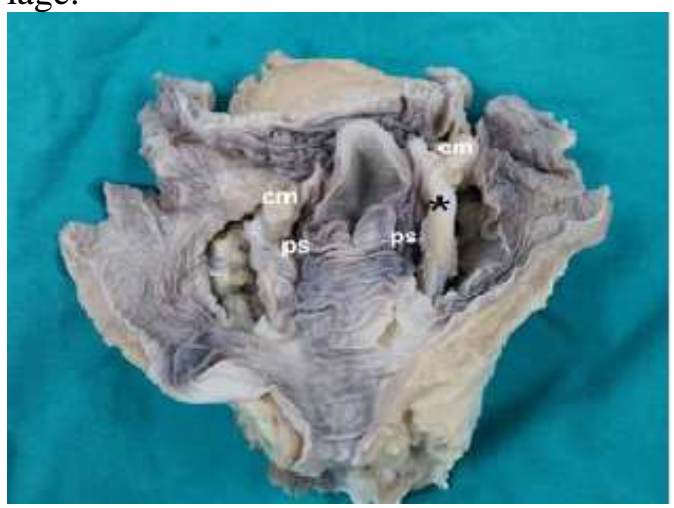

Figure1: Posterior aspect of the hyoidlaryngeal complex. Superior cornu does not seem on the left site. *: Right superior cornu of thyroid cartilage. cm: Greater horn of hyoid bone; ps: pyriform recess.

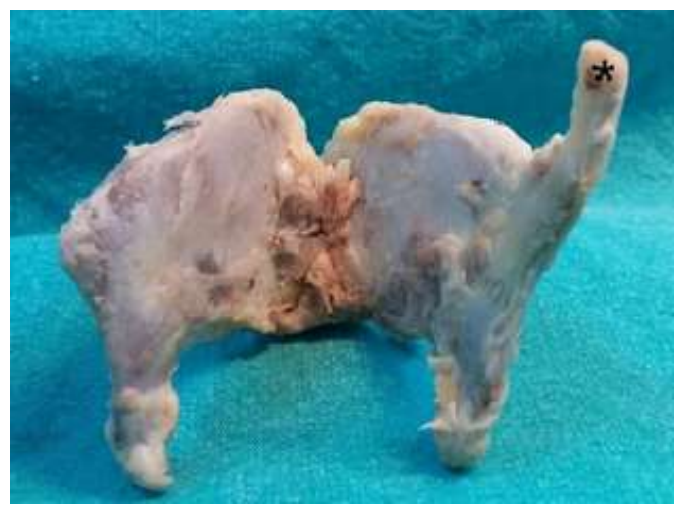

Figure2: Superior cornu does not seem on the left site. *: Right superior cornu of thyroid cartilage.

\section{DISCUSSION}

The agenesis of superior cornu is one of the anatomic variations of the thyroid cartilage. Sometimes it can be complete agenesis of one or more cornua ${ }^{2}$. In the literature, the agenesis of superior cornu has been reported very rarely ${ }^{3-5}$. In a series of cadaver studies conducted by Harjet ${ }^{3}$, bilateral agenesis and unilateral agenesis of superior cornu was found to be $0.9 \%$ and $1.3 \%$, respectively. All of the unilateral agenesis were on the left side. In the case that we have presented, the agenesis of superior cornu was noticed on the left side. In this state, our case shows similarities with the cases of Harjet.

When the agenesis of superior cornu was in question; the presence of a prolonged triticeal cartilage or abnormal bone corresponding to the superior cornu between laminae of thyroid cartilage and hyoid bone on the side of the agenesis has been mentioned. Joshi et al. have described left superior cornu agenesis which has a long spindle triticeal cartilage ${ }^{4}$. Browning and Whittet have reported a case with an abnormal bone between a short superior cornu and hyoid bone ${ }^{5}$.

Superior cornu may be dislocated after trauma besides the cases of congenital absence. In particular, superior cornu can be broken in bimanual strangulation events from the front and can be localized to a different place outside the normal location. In addition, fractures can be found with age associated with increased calcification. Laryngeal manipulations may also cause these fractures which are performed to facilitate endotracheal intubation. For the reasons stated above, especially in criminal cases, when the superior cornu was not found in its place, this situation should not be ignored.

In the presented case, hyoid bone and pyriform recess were seen in different anatomical positiones as generally expected. Positional and anatomical changes in the laryngeal skeleton may cause a variety of clinical situations. For example; Hajiioannou et $\mathrm{al}^{6}$ have reported that globus pharyngis and dysphagia with unknown causes could be caused by anatomical differences in thyroid cartilage. 
In conclusion; the agenesis of superior cornu may occur as a structural abnormality of the thyroid cartilage. Therefore, knowledge of these abnormalities will be useful for clinicians, especially for radiologists, forensic experts and surgical branches that are interested in this region.

\section{REFERENCES}

1. Standring S. Gray's Anatomy: The anatomical basis of clinical practice, 40th edition. Churchill Livingstone 2009.

2. Advenier AS, De La Grandmaison GL, Cavard S, Pyatigorskaya N, Malicier D, Charlier P. Laryngeal anomalies: Pitfalls in adult forensic autopsies. Med Sci Law 2014; 54:1-7.

3. Harjeet JI. Agenesis of superior cornua of thyroid cartilage in northwest indians. Journal of The Anatomical Society of India 1989; 38: 37-40.

4. Joshi MM, Joshi SS, Joshi SD. Absence of superior cornua: a rare variant of thyroid cartilage anatomy. International Journal of Students Research 2011; 1:88.

5. Browning ST, Whittet HB. A new and clinically symptomatic variant of thyroid cartilage anatomy. Clin Anat 2000; 13: 294-7.

6. Hajiioannou JK, Florou V, Kousoulos P. Superior thyroid cornu anatomical variation causing globus pharyngeous and dysphagia. Case Rep Med 2010; 2010: 142928. 